\title{
Analysis of Stimuli Attracting Customer Buying Behavior and their Satisfaction Level in Modern as Well as in Conventional Retail Stores
}

\author{
Dr. Dipin Mathur, Manoj Kumar Sharma \\ (Associate Professor, Advent Institute of Management Studies, Udaipur, India) \\ (Research Scholar, Mewar University, Gangrar, India)
}

\begin{abstract}
The paper highlights the stimuli that attract a prospective buyer in modern retail mall and conventional stores and researcher made a comparative analysis of those variables between modern retail format and conventional retail store. The purpose of this research is specifically to compare the level of satisfaction of the customers with the offerings and attributes offered to them in modern retail formats vis-à-vis conventional shopping stores.
\end{abstract}

\section{Introduction}

Richard, (2011), Consumer Behaviour studied the shopping habits of consumers to form an idea of whether or not the store concepts, product ranges and strategies of the companies are appropriate towards consumer requirements.

Customers are satisfied when the perceived service meets or exceeds their expectations. They're dissatisfied when they feel the service falls below their expectations. When retailers provide unexpected services, customers will be delighted. Thus, to delight customers, retailers need to understand the customer's expectations and take the necessary steps to meet the expected service (Raut and Dash 2011). The consumer is no longer shopping from the local market; rather the place of shopping has shifted to the stores in malls. Malls are also towards catering to the younger population segments. Shopping behavior of the consumer varies according to their age. Moreover shopping behavior of younger consumers' is focused towards seeking entertainment, while older consumers focus on convenience and leisure. India is currently in the second phase of evolution, that is, consumer demand organized formats (Jhamb and Kiran, 2012).

According to Kotler, Keller, Koshy and Jha (2012) "Customer Shopping Behaviour is the study of how individuals, groups and organizations select, buy, use and dispose of goods, service, idea, or experiences to satisfy their needs and wants".

\section{Objective of the Study}

\section{Research Methodology}

"To explore the stimuli that attracts a prospective buyer and compare the level of satisfaction of the customers with the offerings and attributes offered to them in modern retail formats vis-à-vis conventional shopping stores."

\section{Research design}

In this research descriptive research design is used.

Sampling Procedure

The present study is related to the customer's buying behaviour visiting different retail store format for shopping in Udaipur.

\section{Data Collection}

For data collection, sources are-

$\square$ Primary data: This data is collected by the help of questionnaire.

$\square$ Secondary data: This data is collected by the help of internet, books, articles, \& journals.

\section{Research instrument}

Questionnaire is used as one of the research instrument 


\section{Facts And Findings-Data Analysis And Interpretation \\ Table 1: Ranking the features of Conventional shopping store}

\begin{tabular}{|l|c|c|}
\hline \multicolumn{1}{|c|}{ Features } & $\begin{array}{c}\text { Mean Rank } \\
\text { Score }\end{array}$ & Rank \\
\hline Bargain and easily negotiable & 3.34 & 6 \\
\hline Convenient & 4.92 & 1 \\
\hline Credit facility & 4.54 & 2 \\
\hline Loyalty & 3.24 & 7 \\
\hline Purchase in small quantity & 3.93 & 4 \\
\hline Nearness/Proximity & 4.28 & 3 \\
\hline Personalize attention & 3.59 & 5 \\
\hline
\end{tabular}

It is evident from the above mentioned table that when respondents were asked to rank the features which persuaded them to buy from Conventional Shopping Store then (according to the mean rank score), respondents have given $1^{\text {st }}$ rank to "Convenient", $2^{\text {nd }}$ rank to "Credit Facility", $3^{\text {rd }}$ rank to "Nearness/Proximity" and successively $4^{\text {th }}, 5^{\text {th }}, 6^{\text {th }}$, and $7^{\text {th }}$ rank to "Purchase in small quantity", "Personalize attention", "Bargain $\&$ Easily Negotiable" and "Loyalty" respectively.

The data thus exhibit that convenience is the main cause for approaching conventional stores for the shopping by its customers.

Table 2: Ranking the features of Modern retail store

\begin{tabular}{|l|c|c|}
\hline \multicolumn{1}{|c|}{ Features } & $\begin{array}{c}\text { Mean } \\
\text { Rank } \\
\text { Score }\end{array}$ & Rank \\
\hline Wide variety under one roof & 8.03 & 1 \\
\hline Modern looking features & 6.73 & 3 \\
\hline Discounts and schemes, offers & 7.55 & 2 \\
\hline Pleasure, comfort and entertainment & 5.80 & 6 \\
\hline Self comparison between various products brands & 5.78 & 7 \\
\hline Appropriate number of billing counter & 5.39 & 9 \\
\hline Products in the store are reasonably priced & 5.83 & 5 \\
\hline Easy recognition though visual display & 6.01 & 4 \\
\hline Convenient as bulk buying is required & 5.52 & 8 \\
\hline Effective handling of customer queries by employees & 4.53 & 10 \\
\hline Proper parking space & 4.12 & 11 \\
\hline
\end{tabular}

It is depicted from the above mentioned table that when respondents were asked to rank the features which persuaded them to buy from Modern Retail Store then (according to the mean rank score), respondents have given $1^{\text {st }}$ rank to "Wide variety under one roof", $2^{\text {nd }}$ rank to "Discounts, schemes and offers", $3^{\text {rd }}$ rank to "Modern looking features" and successively $4^{\text {th }}, 5^{\text {th }}, 6^{\text {th }}, 7^{\text {th }}, 8^{\text {th }}, 9^{\text {th }}, 10^{\text {th }}$ and $11^{\text {th }}$ rank to "Easy recognition through visual display", "Products in the store are reasonably priced", "Pleasure, comfort \& entertainment", "Self comparison between various products brands", "Convenient as bulk buying is required" ", "Appropriate number of billing counter", "Effective handling of customer queries by employees", and "Proper parking space" respectively. Thus people approach modern retail stores because large no. of variety of goods is available under one roof.

Table 3: Are you satisfied with the offering and attributes provided by conventional shopping stores or modern retail store from where you purchase?

\begin{tabular}{|c|c|c|c|c|}
\hline \multirow{2}{*}{ Response } & \multicolumn{2}{|c|}{ Modern } & \multicolumn{2}{c|}{ Conventional } \\
\cline { 2 - 5 } & $\mathbf{N}$ & $\mathbf{\%}$ & $\mathbf{N}$ & $\mathbf{\%}$ \\
\hline Yes & 238 & 79.33 & 237 & 79.00 \\
\hline No & 62 & 20.67 & 63 & 21.00 \\
\hline Total & $\mathbf{3 0 0}$ & $\mathbf{1 0 0 . 0 0}$ & $\mathbf{3 0 0}$ & $\mathbf{1 0 0 . 0 0}$ \\
\hline
\end{tabular}

The above table depicts that whether they are satisfied with the offerings and attributes provided by Conventional Shopping Stores or Modern Retail Store from where they purchase. 
From the respondents of Modern Retail Store, 79.33\% said "Yes" (they are satisfied) while 20.67\% said "No" (they are not satisfied). Thus most of the customers of the store are satisfied with the offerings and attributes provided by it.

And from the respondents of Conventional Shopping Stores, 79.00\% said "Yes" (they are satisfied) while $21.00 \%$ said "No" (they are not satisfied). The same result is thus found in Conventional buyers. They are also satisfied from offerings and attributes provided by Conventional Shopping Stores.

Table 4: How would you rate your satisfaction level?

\begin{tabular}{|c|c|c|c|c|}
\hline \multirow{2}{*}{ Response } & \multicolumn{2}{|c|}{ Modern } & \multicolumn{2}{c|}{ Conventional } \\
\cline { 2 - 5 } & $\mathbf{N}$ & $\mathbf{\%}$ & $\mathbf{N}$ & $\mathbf{\%}$ \\
\hline Highly satisfied & 70 & 23.33 & 80 & 26.67 \\
\hline Satisfied & 118 & 39.33 & 104 & 34.67 \\
\hline Moderate & 70 & 23.33 & 93 & 31.00 \\
\hline dissatisfied & 33 & 11.00 & 13 & 4.33 \\
\hline Highly dissatisfied & 9 & 3.00 & 10 & 3.33 \\
\hline Total & $\mathbf{3 0 0}$ & $\mathbf{1 0 0 . 0 0}$ & $\mathbf{3 0 0}$ & $\mathbf{1 0 0 . 0 0}$ \\
\hline
\end{tabular}

The distribution of data in the above table shows the satisfaction level of respondents of Modern and Conventional Stores. From the respondents of Modern Retail Store, 39.33\% are satisfied, 23.33\% are highly satisfied and same $23.33 \%$ are moderately satisfied, $11.00 \%$ are dissatisfied and $3.00 \%$ are highly dissatisfied. Thus majority of customers are satisfied either highly, average or moderate from the shopping from Modern Retail Store.

While from the respondents of Conventional Stores, $34.67 \%$ are satisfied, $31.00 \%$ are moderately satisfied, $26.67 \%$ are highly satisfied, $4.33 \%$ are dissatisfied and remaining $3.33 \%$ are highly dissatisfied. Thus the same response is there in case of conventional too as depicted in Modern Retail Store.

\section{Conclusion}

As it is quite evident that the research is bending towards an end, and after having an exhaustive representation of the facts and findings of the research it would be justifiable to mention the conclusion drawn from the research without which the research seems to be baseless and in order to provide meaning to the research the researcher in this chapter has also incorporated the suggestions emanating from the research work. It leads to conclude that factors affecting consumer buying behaviour are significant while making choice of retail outlet by consumers that whether they prefer conventional shopping stores or modern retail format. People are highly satisfied with the offerings and attributes provided by Conventional Shopping Stores or Modern Retail Store from wherever they purchase as the data represents.

\section{Suggestion}

People move to conventional stores preferably because it is convenient for them to buy goods from such store. Nearness and convenience are two important factors on which organized retailers should focus on to attract more of potential customers and conventional stores should try to keep a good variety of products in their store which will help them to attract more of capable buyers.

\section{References}

[1]. Engel, J. F., Blackwell, R. D., and Miniard, P. W. (1986), "Consumer Behaviour, $5^{\text {th }}$ ed., Dryden.

[2]. Foxall, G.R. (1987), Consumer Behaviour, pp. 124-146. In Baker, M.J. (1987), The Marketing Book, Heinemann Professional Publishing.

[3]. Jhamb Deepika and Kiran Ravi, Middle-East Journal of Scientific Research 11 (4): 481-490, 2012, ISSN 1990-9233 (C) IDOSI Publications, 2012.

[4]. Kothari C.R., "Research Methodology Methods \& Techniques", Second Edition, New Delhi: New Age International publisher, 2004, PP. 1-2.

[5]. Kotler, Keller, Koshy and Jha (2012). Marketing Management, 13th edition, published by Pearson Education, pg-144, $432,453$.

[6]. Raut Manmath and Dash Saroj Kumar (2011), The Factors predicting Buying Behavior in Organized Retailing, International Journal of Business and Management Tomorrow Vol. 1 No. 3, p-2.

[7]. Richard 2011, Consumer Behaviour Theories, The WritePass Journal October 20, p-2-5. 